\title{
Corn \& Arak (Local Alcohol) as an Alternative to Bread \& Wine in the Catholic Ritual of the Eucharist (A Deconstructive Analysis of the Novel "Lembata")
}

\section{Yohanes Orong}

Ledalero Catholic School of Philosophy, Maumere, Flores, NTT, Indonesia juanorong15@gmail.com

\begin{abstract}
The purpose of this article is to analyse deconstructively an idea expressed in the novel, "Lembata", by F. Rahardi. The novel takes its name from an island in the Province of Nusa Tenggara Timur, in Eastern Indonesia. The majority of the people there are Catholic. A priest, Pedro, is given a task there by his bishop. In Lembata, he struggles with the basic problem faced by the people, poverty. Of course that poverty is a complex matter. Facing this, he is concerned by the need to import altar bread and grape wine for use in the Eucharist. He sees this as being an example of the Catholic Church supporting capitalism, which he identifies as the root cause of poverty. Pedro takes a controversial stand. He takes local foods, corn and arak, and uses these in the ritual of the Eucharist, instead of imported bread and wine. Written in a deconstructive way, the novel has elements that have relevant values relating to the way injustice can be perpetrated under the guise of promoting religious piety. As well as raising the question about the possibility of using alternative material to what is the norm in a religious ritual, the novel, "Lembata", also speaks about the concept of deconstruction and the attitude of the Catholic Church to poverty.
\end{abstract}

Keywords: arak, corn, deconstruction, host, wine. 


\begin{abstract}
Abstrak
Artikel ini bertujuan untuk menjelaskan gagasan dekonstruktif yang terkandung di dalam novel "Lembata" karya F Rahardi. Judul novel adalah nama sebuah pulau yang terletak di Provinsi Nusa Tenggara Timur, di bagian timur Indonesia. Di provinsi itu penganut agama Katolik adalah mayoritas. Seorang imam bernama Pedro ditugaskan oleh uskupnya di Lembata. Di sana ia bergumul dengan persoalan paling mendasar yang mengancam umatnya, yakni kemiskinan. Tentu saja kemiskinan itu kompleks, tetapi Pedro melihat melalui kewajiban untuk memakai barang impor hosti dan anggur dalam ekaristi, Gereja Katolik melanggengkan kapitalisme yang menurutnya menjadi akar masalah kemiskinan. Pedro kemudian melakukan tindakan heroik, yakni menjadikan "jagung titi" dan "moke”, - makanan dan minuman lokal - sebagai pengganti hosti dan anggur dalam ritus ekaristi yang dirayakannya. Dengan menggunakan teknik penulisan secara dekonstruktif, novel ini jika dibaca berdasarkan kajian postrukturalisme sastra mengandung unsur-unsur dekonstruksi yang nilainya relevan terhadap upaya melawan ketidakadilan sosial atas nama agama dan kesalahen religius. Hasil kajian membuktikan, selain berisikan gagasan pokok tentang upaya menggantikan hosti dan anggur dengan "jagung titi" dan "moke", novel "Lembata" juga berbicara tentang dekonstruksi konsep dan sikap Gereja Katolik terhadap kemiskinan.
\end{abstract}

Kata kunci: moke, jagung titi, dekonstruksi, hosti, anggur.

\title{
Introduction
}

"Jagung titi" is a kind of corn prepared in a special way (Asean, 2020), while "moke", is a form of alcoholic drink most favoured by the people of East Flores, in the Indonesian province of Nusa Tengggara Timur .(Nadeak, 2019). Not just popular foods, "jagung titi" and "moke" have become symbols of the local community. If tourists were to visit the eastern parts of Flores, traversing the islands of Solor, Adonara, and Lembata, the quickest way for them to get to know the people there would be to share a serving of these culinary specialities .(Haqiqi, 2020).

166 |VOL. 9 NO. 2 DECEMBER 2020 
These foods are used by the author of the novel, "Lembata", F. Rahardi, to oppose the domination of the usage of bread and wine in the liturgy of the Catholic Church. Father Pedro, the main character in the book, is a Catholic priest who has the courage to take a controversial stand, and it would appear that he is the only Catholic priest to have ever done so. The purpose of this action was not to cause trouble, but rather to help renew the face of the Church.

This novel is not the result of scientific research. However, if it's contents are read from a perspective of deconstruction, that is a method or way of reading a text in such a way that those contents are deconstructed then reconstructed with an intention of improvement, it truly does contain valid information regarding the genealogy of an isolated group of people, who have been to some extend left behind and forgotten by the world at large. Using "Lembata" as the title, the author suggests that this is a project of deconstruction which intends to lessen the intensity of binary opposition. In this way, the main elements don't excessively dominate others. In fact the opposite happens: early matters which at first were not stressed, such as the degradation and marginalisation experienced by eastern people, minority groups, farmers and sap-tappers who enjoy "jagung titi" and "moke", can receive appropriate attention which is balanced and proportional.

Using "Lembata", the name of a small island just east of mainland Flores, as the novel's title, helps the reader to understand pluralism, and is a manifesto about an isolated society. However, this is not the purpose of this reflection. It describes an effort to try using "jagung titi" and "moke" as a replacement for bread and wine in the 
Corn \& Arak (Local Alcohol) as an Alternative ...

liturgy of the Catholic Church. The novelist uses deconstructive imagery to expose the roots of poverty in this part of eastern Indonesia. (Swasono, 2007). At the same time, he presents the ability of the local community to oppose the domination of western capitalism.

The declaration of the usage of "jagung titi" and "moke" replacing bread and wine in the liturgy of the Catholic Church, is not an attempt to oppose in order to satisfy the writer's imaginative desire. Rather, it is intended to make church-life more contextual and relevant. In doing so, this novel opens a door for a theological discussion about the importance of using local food and drink as a replacement for bread and wine. Before speaking about his findings and raising the issues, the author presents his method of writing and a conceptual study of deconstruction as an approach in literary criticism

\section{Method}

Making use of a descriptive qualitative method of research, the novel, "Lembata" was read taking a deconstructive approach. Text interpretation as explained by Moch. Lukluil Maknun, Umi Muzayanah (2020) aims to determine the contents of the text. The form of the data of this research could be seen in phrases and sentences used in the novel. The primary source of the research was the novel itself, while secondary sources were written documents regarding the study of literary texts, viewed from the perspective of deconstruction.

The technique of gathering data used was non-interactive, and it involved content analysis of documents and archive materials. The means of doing this was constant rereading of the novel, collecting and studying theories relevant to the theme of research, noting, and analyzing all quoted data related to the issue. (Ghofur, 2014). This 
utilized the flow model of analysis. The flow model of analysis began with the collating of data, the editing of that data, displaying it, and finally drawing conclusions. The technique of validating data was that of triangulation of that data. This was done by utilizing data from the primary source, the novel, "Lembata", with supportive material from other texts relevant to the study of deconstructing a novel.

The primary questions of this study are, "Why does the novel, 'Lembata', deconstruct the usage of bread and wine in the Eucharistic celebration of the Catholic Church, and exactly how is the element of deconstruction elaborated?"

\section{Literatur Review}

\section{Deconstruction as an Approach to Literary Criticism}

Paul Budi Kleden at the beginning of his critique of the novel, Lembata, quoted the following statement of Albert Camus: "Essentially, a modern writer cannot give him/herself to serve those who make history. On the contrary, the writer must honour the importance of those who are victims of history. If not, he/she betrays themselves and their art .(Kleden, 2009)." Albert Camus made this statement when he received the Nobel Prize for Literature in Oslo, on $10^{\text {th }}$ of December, 1957. Kleden took this as meaning that for Camus, art is not something for one's personal pleasure, but a means of speaking to as many people as possible, by putting before them a shared vision of suffering and joy. Artists see the importance of their work as always being rooted in two obligations that are not easy to fulfill, namely rejecting deception and opposing oppression. (Kleden, 2009) 
With this in mind, the idea of deconstruction disarming reality and history, which has for a long time been based on the construction of the victors, is proposed. Thus, a strong correlation can be seen between the ideals of a work of art and efforts to dismantle the establishment. There is an affirmative connection between the effort to create a novel and the most universal purpose of such a creation, namely the dismantling of the status quo and renewal of reality. An effort to dismantle the establishment is a realization of the anxiety of post modern humanity regarding various forms of modernist failures. Suspicion and disarmament of failures of modernism is the dialectic of renewal which is often found in correct literature.

This is the point where deconstruction is located. According to the philosopher, Jacques Derrida, who is the originator of the theory of deconstruction and quoted by Heri Santoso, (2009, pp. 147-148) humanity is entering an era that is completely different from the modern one. Many thinkers are of the opinion that the modern era is dying and is in the process of being replaced by post-modernism.

Basically, the post-modern era has come about as a reaction to the non-realisation of what had been idealised in the modern era (Ratna, 2010). The modern era, which took root between the $15^{\text {th }}$ and $18^{\text {th }}$ centuries then reached its zenith in the $19^{\text {th }}$ and early $20^{\text {th }}$ centuries, could be described as having 5 ideals: reason, nature, happiness, progress and liberty. Considering reason, the ideal of modernists depends on research or the expression of truth as undertaken according to humanity's rationality.

In the middle ages, that time prior to the modern era, obedience to the authority of the Church and what could be described as spiritual or supenatural, was greatly stressed. Then in the modern era, there had 170 |VOL. 9 NO. 2 DECEMBER 2020 
been a growth in trust, and sole dependence on, human reason which was supported by methods of observation, experimentation and research. Modernist thinkers were convinced that humanity, which has the ability to think, could use reason to always find the truth. That truth was absolute, one, objective and universal. Humanity was seen as homo-autonomos, meaning that humanity itself determined truth, law, and indeed its own destiny.

Nature is a concept which indicates the efforts of modernists to free humanity from the supernatural, focusing purely on the natural. This focus was expressed by constant reference to the mystery of nature. The modernists are taught that the position of humanity was very much influenced by its acceptance of nature, and acknowledging its own place in nature.

Broadly speaking, the five ideals of modernism mentioned earlier could be realised in science, technology and economic growth. These three fields don't stand alone, but are interconnected. Science which results from experiments and research of nature, is the solid foundation for the advancement of technology and economic growth universally. (Anisa, 2013)

It should be acknowledged that the modernist spirit has certainly enabled great advances to happen in human life. However, when the dreams of humanity seemed to be about to be realised, people were surprised by events which actually pushed those dreams away. The first and second world wars were realities that devastated the dreams of the modernists. Also the appearance of pollution on a grand scale, the desecration on the environment, exploitation of workers, slavery, ethnic cleansing in various places, increasing crime, racism, terrorism, 
Corn \& Arak (Local Alcohol) as an Alternative ...

breakup of national states, and ongoing wars are the bitter inheritance of the modernist ethos which must be acknowledged and recognised.

In a more actual and relevant context, where is war, inter-ethnic fighting and racial oppression, deconstruction as stated by (Weber, 2005) can be seen as an alternative point-of-view which stresses justice. In her text, Deconstruction is Justice, which is dedicated to Derrida, Elisabeth Weber writes:

It is in the spirit of such urgency, of a responsibility that cannot be postponed, that Jacques Derrida was an active and outspoken critic and commentator on issues such as South Africa's apartheid, the Israeli-Palestinian conflict, the bloody civil war in his native Algeria, human rights abuses, French immigration laws, the death penalty, and on what Richard Falk has termed "the great terror war". (Weber, 2005, p. 179)

Weber praises Derrida and the concept of deconstruction he developed. According to Derrida, in a living situation which is filled with all kinds of social injustice and negative realities which disturb humanity, deconstruction is an antithesis to different forms of tyranny and ideological indoctrination, which have been committed by the perpetrators of evil. When science and technology fail to solve all the problems of humanity, deconstruction can be an alternative argumentation to address the situation.

Post-modernists such as Derrida claim that modernism has created a universal truth that could be described as being monotone, positivistic, rationalistic and technocentric. According to them, this is a form of enchaining freedom, and therefore considered as failing to complete the project of enlightenment. (Hidayat, 2008)

Current modernism, as noted by Yasraf Amir Piliang (2011), in a hegemonic way has produced information technology which has gone beyond global barriers, and has reduced the size of the world.

172 VOL. 9 NO. 2 DECEMBER 2020 
However, Piliang shines light on a striking contradiction in progress. According to him, "Globalization evidentially does bring a certainty of values, or the stability of a hegemonic power, as dreamed by imperialists. Rather, it leads to an uncertainty of values, an epistemological confusion, and finally to an ontological unsafety which points in the direction of cultural irony." (Piliang, 2011, p. 364)

Deconstruction is a post-modern philosophical trend which has been developed by Jacques Derrida .(Bertens, 1996). It possesses a character which is the opposite of modernism. It gives more importance to emotion than to reason, and regards the medium as being more important than the contents, the sign as being more important than the meaning, and possibility as being more important than certainty. (Artho, 2011) Deconstruction criticizes modernism, especially in its claim to create a universal truth.

For Derrida, the world is full of uncertainties. Uncertainties should be celebrated. In doing so, the meaning of uncertainty can be found. Human beings have a right to interpret their life freely, in order to discover a new meaning as a tool to deal with life that is in constant flux. As an effort to liberate, deconstruction has a fertile life in the midst of the world's uncertainties. Supported by the progress of the economy and information media, deconstruction expresses itself in creative and flexible ways, such as art, literature, design and architecture.

Deconstruction is also present in people who question themselves when facing uncertainty in the world. Deconstruction plays a role at the level of reflection, by delaying a declaration of truth, while searching for new meanings from experience, for example by tracking 
Corn \& Arak (Local Alcohol) as an Alternative ...

and exposing the meaning and implications of state management, while challenging the truths and moral teachings of a religious institution. An exposure is made with bravery, revealing structural deceit which many people are unable to reject because of what is happening to them at the present moment.

Technically, deconstruction as an approach in the study of literature is methodological. This means, as stated by Tommy F. Awuy, (1995, p. vii) that it is very useful to "break through the thought patterns and cultural works which seem to be so orderly and clean.

Because of this we accept these as a given fact." At least it can be said that modernism contains in itself a constructivism of truth and a law of identity linking concrete reality and abstract concepts, and also connecting the signifier with the signified. (Hardiman, 2015) This phenomena, according to Awuy not only is an identification of Western culture, but also is universal. (Awuy, 1995, p. vii) Here, the function of deconstruction is to disarm those elements which have been fatal for human awareness regarding what need not be accepted rationally. Deconstruction is a means of demolishing the mystification of the progression of a culture. In recent times, many works of literature, especially novels, have thrown light on that theme of demolition. Many novel writers have become aware that, in the end, humanity must evaluate the process of living that they have been participating in. This evaluation act like a pause which can be used to break with the establishment that lulls consciousness, caused by an ideology of modernism. This must be done according to Piliang as "the turning point of modern civilization." (Piliang, 2011, p. 183) This turning point identifies a way of evaluating and at the same time 
demolishing the road of modernization. Thus consciousness emerges as a part of the post-modernism narrative.

Post-modernism is the turning point of modern civilization. (Piliang, 2011, p. 183). Piliang (2011, p. 184) says the following: "At the ideological level, what is said as being the turning point of an ideology is the turning back of the current and the ideological foundation from what is called the grand narrative, to little narratives. This turning point explains how claims of universalism, humanism, rationalism and foundationalism which construct the main ideology of the present time, experience a loss of strength, a means of criticism and legitimacy. With the appearance of the wave of post-modernism, new claims are made referring to pluralism, relativism, localism, indeterminism, and anti-fundamentalism."

Following on from this, Piliang (2011, p. 184) explains that the narrative at the beginning is better known as a literary expression, much the same as a story, such as a novel, legend or myth. However, J. F. Lyotard and Fredric Jameson use this expression in a broad epistemological context, as a narrative of life, through which humanity can express concepts, understand life and find the meaning of reality. Through a narrative, the world is presented through various concepts, ideas and stories, which need ways of interpretation. A narrative then gives form to a collective consciousness in the human person. A narrative can feature contradictions and can destroy old value structures in society. (Piliang, 2011, p. 184)

An awareness such as this methodologically can be built upon a setting to work of deconstruction, that is the destruction and the stripping of the constructivism of evidence which has been distorted by 
a hegemony of truth and the ideological claims of the concepts of modern humanity. This can be seen in the form of building global competitiveness, reaffirming the knowledge and practical expressions human freedom which have been disregarded, as well as groups at the bottom of society without knowledge or representation (Morton, 2008).

In the world of literature, this setting to work of deconstruction can, for example, be realized in the form of a short story or a novel which portrays the destruction and opposition of the lower class which has for a long time been ignored in social life. An example of this has been noted by Morton, (2008, p. 95) in the short story, "The Elephant and the Tragopan Pheasant", by Vikram Seth. In this work, Seth uses the convention of an animal fable which is written in rhyming couplet form. It presents the building of a dam in a fictional valley called Bingle. In order to oppose the construction of the dam, an elephant and a pheasant engage in a campaign to save the valley and all the animals who live there, from the destruction of their habitat. In this story, Seth invites his readers to interpret the struggle of the animals to defend their environment, as an allegory for the struggle of simple farmers whose way of life is being threatened by the greed of people in power. (Morton, 2008, pp. 95-96)

Deconstruction, as understood in this short story, is an approach in the study of literature, by which readers are brought to a methodology which probes contradictory elements of a literary work. Considering this, it is not an exaggeration to say that deconstruction can be understood as a provocation which is anti-establishment and opposes certain claims of certain truths.

Sindunata (2007) writes that deconstruction can be understood as a provocative movement that has come from a long way off, which 176 |VOL. 9 NO. 2 DECEMBER 2020 
seems as though it cannot be accessed but must be accessed, which is beyond humanity but must be reached by humanity. According to Sindunata, nobody can escape the evidence of destruction.

Donny Gahral Adian takes a more extreme view saying that deconstruction is a battle against the absolutism of meaning. On this level, reality begins to be left behind and people move towards hermeneutic evidence. Reality is something which is stated in the text of a discourse, while knowledge is linguistics. (Piliang, 2010, p. xxiii)

Sindunata and Donny Gahral Adian are both correct. Why? In the context of the life of post-modern humanity who no longer understand the meaning of life as being determined by natural reality in the circle of life, deconstruction tracks every construction of discourse. Non-natural reality is reality which is formed in an image, for example as on television. (Piliang, 2010, p. xxiii) When reality is understood as evidence formed by discourse and human language, efforts to track that discourse become very important. On this level, deconstruction is present as a cutting knife, which helps humanity to discover alternative rivals in the midst of world developments which are effected by the disappearance of authenticity.

Deconstruction is present in the mind of a self-questioning person who faces the uncertainties of life. (Derrida, 2002) Deconstruction plays on the level of reflection by delaying expression of truth. It uncovers new meanings from experience, for example, reviewing meaning and the implication of state control while reflecting upon the truth and moral demands of a religious institution. Deconstruction needs to be tempered with bravery to expose structural 
Corn \& Arak (Local Alcohol) as an Alternative ...

falsehoods which make many people unable to reject matters which they are currently experiencing and accepting.

F. Rahardi in his novel, Lembata, brings to the fore in a very forceful way, elements of that deconstruction. This novel was published by Lamalera Press in 2008. Yohanes Orong reviewed it in 2012, basing his thesis on what he was studying at Universitas Sebelas Maret Surakarta. Later, in 2019, Orong published an extract of that thesis in the Social Science Humanities Journal, in which he focused on values in education. Lembata, the title of the novel, is the name of an island in the Province of Nusa Tenggara Timur, in Eastern Indonesia.

The lack of progress on the island as pictured by Rahardi, is not just caused by corrupt leaders who often collaborate with developers who use poverty as a commodity to obtain projects. Another cause of the inability of the Lembata society to escape poverty is the sin of capitalism which infects every part of human life, including the Catholic Church. The usage of wheat bread and grape wine in the Eucharist can be seen as condoning a capitalist practice.

In opposing the insistence of the usage of bread and wine, the novelist proposes that these foreign things be replaced by local products, namely corn and arak, (palm wine/spirit). The primary focus of this article is on an elaboration of this theme. Another theme of focus which is related to the primary one, is an evaluation of the concept and attitude of the Catholic Church to poverty. This will be raised in the second part of the article.

\section{Result and Discussion}


Three important features of the concept of deconstruction are: a rejection of logocentricism, absolute truth and the dichotomy of subject and object. (Tana, 2020) In this novel, these three features are presented primarily in an evaluation of holiness in the Catholic Church. In the person of Father Pedro, the usage of the bread and wine in the celebration of the Eucharist in the Catholic Church, is deconstructed, and the commitment of Father Pedro to assist the people of Lembata to come out of poverty, is a presentation of the deconstruction of the concept and attitude of the Catholic Church to poverty. These two features of deconstruction will be discussed in the following section.

\section{Deconstruction of the Bread (Host) and Wine}

The struggle of Father Pedro to try to address the poverty of the people of Aliuroba, a parish in Lembata, is the beginning of his effort to deconstruct something regarded as a taboo, holy topic. In spiritual matters and sacramental services, the Catholic Church is very much tied to religious traditions which insist that bread and wine are symbols of the Body \& Blood of Christ in the celebration of the Eucharist. (Waligereja Indonesia, 2007) Using something other than bread and wine is a taboo topic for discussion. Doing so would have serious repercussions.

As a priest, Father Pedro knows well the requirement of using bread and wine in the celebration of the Eucharist. He himself has long followed this rule. The Catholic Church maintains this tradition essentially because it is a fact that in the Last Supper before he left his disciples, Jesus Christ used bread and wine. However in the face of the 
poverty of the little people of Aliuroba, Father Pedro has thoughts about the possibility of using other symbols, which would be cheaper and more easily obtained, to replace bread and wine.

In the home of the old man, Longginus, Father Pedro reflects, "If Jesus had been born in Lembata, and the Last Supper had taken place here, certainly He would have drank arak and not wine, or at least unfermented palm juice (tuak), From then on, the Eucharist would have used this." (pages 86-87)

Tuak is a drink with an alcohol content between $8 \%$ and $15 \%$ made from the juice of a type of palm tree. This is then distilled, creating a spirit, arak, which has an alcohol percentage of $30 \%$. Sometimes this is further refined, producing a stronger spirit with an alcohol percentage up to $60 \%$. (Kusumo, 2018)

Father Pedro believed that if the Last Supper took place in Lembata, Jesus would have drunk either tuak or arak. This line of thinking took him to a more serious thought, namely that it was important to deconstruct signs and symbols used in the Catholic liturgy. Father Pedro didn't just take this idea "out of the blue". He calculated that if this locally produced alcohol was used in the Eucharist, the Catholic Church would no longer need to import wine from overseas. As well as reducing the financial burden, the economy of the people would also benefit.

.... When taking part in Mass at a station church, the old man, Longginus also contributed to the collection. His donation usually wasn't a big one, just 1000 or 2000 rupiahs. However this money was used to pay for the imported Mass wine, from a Jesuit vineyard in Australia. Father Pedro wondered why this old man who was so poor, should pay the wages of workers in a vineyard in Australia who were much richer than he was. Reflecting on this, he questioned: Why doesn't Canon Law permit the use of local alcohol in Mass? (page 87)

Moving on from these thoughts, Father Pedro pondered another reality, namely the usage of money collected from the poor by the 180 |VOL. 9 NO. 2 DECEMBER 2020 
Catholic Church. The old man, Longginus represents the poor Catholic faithful who feel obliged to contribute to the collection at Mass each Sunday. Father Pedro connects this contribution by the poor to the practice of importing foreign wine. Unconsciously, the poor Catholic faithful of Aliuroba participate in making the richer Australians. After this, Father Pedro disputes the banning of the use of local alcohol in Mass. According to him, if local alcohol was able to be used, the Catholic Church wouldn't need to import wine from Australia. Then the Church could use the money contributed by the poor faithful to help overcome poverty itself.

Father Pedro not only wanted local alcohol to replace wine in the Eucharist, but he also wanted corn to replace the hosts which were a form of wheat bread.. He proposed that corn, a staple food of Lembata which was prepared as Jagung titi be used. This was a food commonly eaten all over the island, which was always offered to him when he visited his parishioners.

The food which the people most commonly shared with Father Pedro when he visited them was corn (jagung titi), with tea or sweet coffee. The spirit, arak, was only drunk on special occasions. The corn was prepared by frying kernels without oil, after which they were smashed by a rock and flattened. They were then dried. Later they could be fried before consuming. The process was similar to that used by Javanese people to prepare a food known as "emping Jawa". (page 94-95)

A long time before Father Pedro became a priest, he used to eat that form of corn. He really liked it. As a child, he and his friends used to pretend to say Mass, using corn as the host.

.... Since he was a child in Larantuka, Father Pedro liked that kind of corn. He and his friends used to often play at celebrating Mass, using red syrup and corn instead of bread and wine. He hadn't yet received his First Communion, so he didn't know what the host tasted like. (page 95) 
However, now as a priest Father Pedro does play with the Mass. He celebrates Mass fully aware of he is doing. He has no desire to make-up his own form of Mass. He must use bread and wine. Drinking arak and eating corn in the homes of his parishioners is different from celebrating Mass in a church where he must use bread and wine. Father Pedro reflects on this reality:

"Why can't corn be used at Mass? Isn't the host which is made from wheat flour then given to the faithful as the Body of Christ, just a symbol? If that is so, surely it can be replaced by other foods such as corn, cassava, or different kinds of sweet potato? Or, if the host must be round in shape, why must it be made from wheat flour imported from Europe or America?

Imported wheat flour is also used to make noodles, as well as bread. Those who mainly eat noodles are poor people, particularly those living in suburbs but also in villages as one finds in the parish of Aliuroba. Why must these poor people financially support wheat farmers in Europe and America who are already very rich?" (page 96-97)

The form of the host in Mass is a symbol that can be changed. Father Pedro develops this argument. He says that in Lembata, there are other foods that could be used. If the host and also the wine are essentially symbols which express the presence of the Body and Blood of Jesus, why can't they be changed? Why must something imported from overseas have this role? This practice has resulted in the people of Indonesia suffering, being caught-up in global capitalism. The Church, too, by using hosts made from imported wheat flour, and imported wine, is caught in the web of capitalism.

The opposition of Father Pedro to the obligation of using wheat hosts and wine in Mass, isn't something uncomplicated. He is aware that in Catholic circles, consideration of changing the sacramental elements of the Eucharist is still a taboo subject:

"Even when I was studying at the major seminary, Ledalero, debating this subject was taboo.

182 |VOL. 9 NO. 2 DECEMBER 2020 
Why must the Church now be like it was in the Middle Ages, banning discussion of something that makes sense, which effects the life of little people? Does the Church opt to support the wheat farmers of prosperous countries by making it compulsory to use hosts made from wheat flour? Hasn't God given freedom to humanity to always raise questions such as this?"(page. 97)

At Ledalero, Father Pedro's alma mater, this matter is still a taboo subject. (Orong \& et.al., 2019) The Cathiolic Church is seen not only as a very conservative institution, which enforces the traditional rule regarding wheat hosts and wine at Mass, but also is a body which is on the side of the developed world. Poverty in Lembata is a logical consequence of this hardened attitude of the Church. Having such a conservative attitude, the Church gives the impression of snatching away from the people the grace of freedom given by God.

Father Pedro has good reason for raising this issue. After years of facing the poverty of Aliuroba, he has discovered evidence that there is hardly any aspect of life that is free from the influence of global capitalism. In light of this fact, the Catholic Churchnot has adopted an attitude of keeping quiet and being indifferent, but also supports the stability of global capitalism.

".... The second matter that causes him to have sleepless nights is information regarding his parishioners, and indeed about the Indonesian people as a whole, who are forced to purchase even the cloth for their underwear from cotton farmers in Texas, USA. He wonders why the Catholic Church says nothing about this, and further more questions whether or not the Church is actually a part of global capitalism." (page 101-102)

It seems as though Father Pedro doesn't just try to deconstruct the usage of wheat hosts and wine in the Catholic Church's Eucharist, but he points out an influence of global capitalism which has more or less been accepted unconsciously for many years. He confirms that $95 \%$ of cotton which is woven in Indonesia actually is imported from 
Corn \& Arak (Local Alcohol) as an Alternative ...

the USA and Kazakstan (page 100). Then Father Pedro lays a charge at the Catholic Church. He knows that cotton is grown in tropical climates. It could be grown in Indonesia. But as far as Father Pedro knows the Church in Indonesia has never spoken about this.

"Why doesn't the Church, and here I mean the bishops and religious orders, never raise this matter? The material used for our national flags, as well as that used by the Church for liturgical garments, all comes from Texas, USA." (page 101)

Father Pedro presents the ideals of deconstruction which don't allow him to just accept the status quo of global capitalism. He is unable to separate the poverty of Aliuroba from global capitalism which has such a huge influence. Also, as he reflects on these things, he realises that he, as a member of the Catholic Church, has done little to address this situation.

“....Pedro is disappointed because the Church doesn't show a great concern for the poverty of the world. He, as a member of the hierarchy, wants to do a lot. He wants at the same time to rebel. Why do the elements of the Eucharist have to be imported? Why can't we use arak and corn? Why is it that the people of Lombok are now consuming more noodles and bread? Why is it that at the seminaries such as Hokeng and Ledalero, and in other religious houses, there's always bread made from imported wheat flour? Why must our poor nation continue to enrich rich nations?" (page 112)

The disappointment of Father Pedro, and his rebellion against the Church, its hierarchy, and against himself, finally must be tested by his extreme decision to challenge the liturgy of the Catholic Church. Consistent with his ideals, Pedro makes a determined commitment to keep-up his struggle and unflagging rebellion.

Finally, that commitment must be tested by his attitude and his actions. If not, the ideals that he professes would be farcical. Father Pedro struggles with his ideals. Not completely sure if he is doing the right thing, he actually does consecrate corn and arak at Mass.

184 |VOL. 9 NO. 2 DECEMBER 2020 
"While celebrating Mass at the Mother of Perpetual Church, Aliuroba, was shaking. In his sermon he told the faithful that he was rebelling against the liturgy of the Church. He said he would drink arak rather than wine, and would distribute crushed corn instead of wheat flour hosts. When he said this, about one third of the faithful attending the Mass left the church, but there was no uproar.Two thirds remained. Father Pedro felt that he had the support of a large proportion of the Aliuroba parishioners. However, when the time came for Communion, about one half of those present came forward to receive the sacrament. This meant that only a third of the faithful approved of using arak and corn at Mass.

Half of those remaining in the church opted not to come forward. So they were divided. One third strongly opposed what had been done, one third accepted it, while the remaining third didn't oppose it, but they didn't want to receive it. The Mass ended in chaos. (page 112-113)

Father Pedro successfully deconstructed the symbols of the Eucharist. He also deconstructed the rigidity of the liturgy of the Catholic Church. The controversial action was risky. The consequences of this weren't easy to deal with. The hardest thing for was not the uproar caused by his action, but rather the seriousness of his commitment to pursue his ideals. Father Pedro was certainly conscious of the fact that in opting to challenge the Catholic Church, he didn't actually have a great influence opposing the power of the Church.

"But the Catholic Church is a power that is very old and very big. It's not possible for a priest, working in a little, poor parish, in a country where the majority of citizens are Muslim to change canon law, especially the laws regarding the Eucharist. In history, there have been numerous public figures who have been crucified, victimised, and/or ostracised, such as Galileo Galilei who was ostracised then "rehabilitated" a couple of centuries after his death. But Father Pedro had done what he had done. He became calm. On the night of that fateful Mass he slept soundly, so different from the week before. (page 116-117) 
Corn \& Arak (Local Alcohol) as an Alternative ...

Even though he didn't succeed in undermining the power of the Catholic Church, Father Pedro experienced a certain success. He could sleep soundly. But he knew that by exchanging the elements of the Eucharist was not the be-all and end-all of realising his ideals. Father Pedro's commitment to his own attitude and option was still going to be tested.

From what has been written above, it can be concluded that Father Pedro succeeded in challenging traditional regulations of the liturgy of the Catholic Church. He did this by changing the elements of the Eucharist. By doing this, he not only caused much angst among his flock, but his actions led him on a journey that was to result in him leaving the priesthood. However, because of his bravery in making this deconstruction, he experienced happiness. As a happy man, he could at least sleep peacefully.

\section{Disarming the Concept and Attitude of the Catholic Church to Poverty}

The project of deconstruction in the novel, "Lembata", is concerned with the struggle to disempower poverty and injustice which are endemic on the little, isolated island of Lembata. Father Pedro, a diocesan priest from the Diocese of Larantuka, has completed his studies in economics at the Atma Jaya University in Jakarta. He has taken up a position as assistant parish priest at the parish of Aliuroba, Lembata. In his opinion, his most difficult task is not sacramental ministry or carrying-out religious rituals, but rather eliminating poverty in Aliuroba. As a diocesan priest, he is aware that his tasks are not limited to serving the Church's liturgical needs.

"....The Jesuits are the ones who emphasise the importance of good liturgy in the building up of the Church. The SVD focus on education and health care. We diocesan priests should empower 186 |VOL. 9 NO. 2 DECEMBER 2020 
our people to overcome poverty. But this isn't easy, and it will take a long time." (page 24)

Father Pedro, a diocesan priest, is challenged to do something to overcome poverty. The place where he is based, Aliuroba, has minimal social facilities.

"If you want to visit Aliuroba, says the dean of the district, there's a problem, as there is nowhere for you to stay. It's a small place. There is electricity. But the generator only works at night. A mobile-phone tower has been constructed, but if the weather is bad, the signal goes." (page 24)

This is where Father Pedro is stationed as assistant parish priest. His friend from university, Luciola, cannot understand why he wants to go to this poor, isolated place.

"Why have you chosen this way of life, Pedro? [He cries when he sees the condition of the parish of Aliuroba.] With your degree in economics from Atma Jaya, you could be sitting in a comfortable air conditioned office in downtown Jakarta. You could travel anywhere by car. And you speak English well. Why, Pedro?" (page 29)

In Aliuroba, Father Pedro comes face to face with real poverty. That poverty is at the heart of so much suffering, and is the root cause of so many other problems. It's the reason why so many young people from Lembata and neighbouring Flores choose to migrate illegally to Malaysia.

"Poverty has forced young people of Flores to leave their homes. Some choose to enter a seminary. The majority of these do not succeed in becoming priests, but they do not return home. Poorly educated ones go to Malaysia. They work hard there in rubber and cacao plantations, and take on other hard labouring jobs. They are strong, diligent, hardworking and honest. But why, when they are home in Flores, Adonara, Solor or Lembata, are so many lazy, dishonest, and heavy drinkers?" (page 60)

Father Pedro discovers that there is no easy answer to such a question. Poverty causes the young people from these islands to seek 
Corn \& Arak (Local Alcohol) as an Alternative ...

their fortune in Malaysia. Going overseas like this raises more problems. He could enumerate those problems, one by one. He wrestles with existential questions about the youth of these islands who become illegal immigrants in Malaysia. Overseas, they are hard working, responsible, quite different from when they are at home.

It seems that only when young people leave their home village do their irresponsible lifestyles go. Is poverty caused by their bad habits such as being lazy, irresponsible, and heavy drinking?

Father Petro is reluctant to blame poor people for causing their own poverty. Rather he looks further afield, asking, "What is behind poverty?" As a priest he is challenged to ask himself, his fellow priests and the institution of the Catholic Church, what is being done to alleviate it?

"Father Alex, as I am a new priest in this parish, may I ask you something?

"What more do want to ask? Are you concerned about Ola's money?"

"No, Father. I just want to know what has been done by the Church to alleviate poverty. Why are the people still so poor?"

“The Church can't do anything except celebrate the Eucharist. By the Church, I mean the institution which is the Parish Council, which we are part of. If the Church is looked at this way, you yourself can see what has been done. We have provided the sacraments, such as baptism, confirmation with the bishop, the last rites, funerals, and Mass is celebrated regularly in the parishes 8 stations. What else can be done?"

"I am not talking about these things, Father. Rather, I am thinking about the Church when it was focussed on being missionary, and looking at our present situation."

"It's true that the people of Aliuroba are poor. The Muslims up north are relatively rich. Here, the people are subsistence farmers. Up north, they are traders. Traders always have more money than farmers. Particularly the ones who work in the paddy fields. You have seen how poor the farmers in Java are, haven't you? I am not trying to justify anything, but just noting the way things are."

188 |VOL. 9 NO. 2 DECEMBER 2020 
"Why do you think those poor people still practise polygamy?"

"Polygamy has got nothing to do with poverty. It's just a part of natural law. Sometimes people behave like doves."

"What do you mean?"

"According to Catholic teaching a couple marries for life. But some people act like fowls."

"You are talking about polygamy?"

"Yes. A rooster services many hens. And there are people who behave like dogs."

"What do you mean?"

"I am talking about polyandry. A bitch will have sex with many male dogs so that it can have a lot of different offspring. There are women and men like that too. So polygamy hasn't got anything to do with poverty, but rather it's connected with natural order of things, as with birds, fowls and dogs. Do you follow me?"

"I understand. But my question about why we have poverty hasn't been answered."

"You are going round and round in circles. People are poor because they are not rich. The world is upside down. Religious men and women, including priests, who take a vow of poverty, live in luxury. You have seen this yourself in Jakarta, haven't you?"

"Yes."

"But the faithful who don't take vows of poverty live in poverty."

"What should we do about this, Father?"

"Let's pray together....or would you prefer to pray alone in your room? Then we will sleep, because tomorrow we will serve those people whom you call poor. Do you follow me?" (page 61-62)

In the dialogue above between the two priests, Father Pedro and Father Aleks, clearly Father Pedro is taking this matter much more seriously than his more senior colleague, Father Aleks. For Father Pedro, the time has come for the institutional Church must take responsibility for the poverty of Lembata. On the other hand, Father Aleks doesn't see poverty as being an issue for the Church. He sees his role as being a priest who serves his people with the administration HERITAGE OF NUSANTARA: INTERNATIONAL JOURNAL OF RELIGIOUS LITERATURE AND HERITAGE 
Corn \& Arak (Local Alcohol) as an Alternative ...

of the sacraments, not by getting involved in issues such as the alleviation of poverty.

Apathetic to poverty, has almost no awareness of the problems faced by his people. His theoretical understanding, for example of polygamy and polyandry, doesn't see the root causes of these practices, and he doesn't see any need to be involved in dealing with the issues these cause in society. Father Aleks just seems to accept the present situation as being "the way things are". It is not the task of the Church to change or improve things.

Possibly Father Aleks' attitude which is so cold and apathetic is influenced by his concept of poverty. He simply defines poverty as being "not rich". He doesn't ask why that is the case. When challenged to do something, he invites Pedro to pray with him...

But for Father Pedro, just praying is not enough. It's not sufficient for priests, bishops and all the Church's hierarchy to just busy themselves with the sacraments. He asks in his heart, "What should the Church be doing to alleviate poverty?"

Based on what is written above, it can be concluded that the deconstruction of the concept and attitude of the Catholic Church by Father Pedro, is pointing in the direction of a transformation of the Catholic Church's concept of poverty and her attitude to it. The Church can no longer do nothing. Priests, bishops and other Church functionaries, cannot limit their work to spiritual and sacramental service. They must creatively try to alleviate poverty as it is presently experienced.

\section{Conclusion}

In actual fact, the Catholic Church has never banned discussion regarding the possibility of using symbols other than bread and wine for the Eucharist. However, such discussion has never produced 190 VOL. 9 NO. 2 DECEMBER 2020 
concrete results. Possibly because he regards this as something that will never happen. As a Catholic writer, F. Rahardi has deconstructed the hardened attitude of the Catholic Church in his novel, "Lembata". Exploring what he has written, one can find at least two elements of deconstruction in this novel, namely a deconstruction of the usage of bread and wine in Mass, and the revealing of the concept and attitude of the Catholic Church towards poverty. If the first element of deconstruction is a matter of fiction which isn't set in a particular time, the second element challenges the Church to take steps now towards creatively address the issue of poverty.

\section{References}

Anisa, D. D. (2013). Dekonstruksi terhadap Aspek Modernisme dalam Roman Die Verwandlung Karya Franz Kafka. Skripsi. Jurusan Pendidikan Bahasa Jerman Fakultas Bahasa dan Seni Universitas Negeri Yogyakarta.

Artho, S. P. (2011). Cika, Aku (Mencintaimu), Posmodernisme dan Cinta. Surabaya: Unika Widya Mandala.

Asean. (2020). Get to know the culinary of Flores, East Nusa Tenggara, named Jagung Titi. Retrieved on November 4, 2020, from Get to know the culinary of Flores, East Nusa Tenggara, named Jagung Titi: https://indonesiar.com/get-to-know-theculinary-of-flores-east-nusa-tenggara-named-jagung-titi/

Awuy, T. F. (1995). Wacana Tragedi dan Dekonstruksi . Yogyakarta: Jentera Wacana Publika.

Bertens, K. (1996). Filsafat Barat Abad XX Jilid II. Jakarta: PT Gramedia Pustaka Utama.

Derrida, J. (2002). Dekonstruksi Spiritual; Merayakan Ragam Wajah Spiritual. Yogyakarta: Jalasutra. 
Ghofur, A. (2014). Analisis Dekonstruksi Tokoh Takeshi dan Mitsusaburo Dalam Novel Silent Cry Karya Kenzaburo Oe Perspektif Jacques Derrida. OKARA, Vol. I, Tahun 9, Mei 2014, 72.

Haqiqi, M. I. (2020). Jagung Titi, Contoh Nyata Bagaimana Masyarakat Lamaholot Menciptakan Ketahanan Pangan. Retrieved in 2020, from Jagung Titi, Contoh Nyata Bagaimana Masyarakat Lamaholot Menciptakan Ketahanan Pangan: https://mojok.co /terminal/ jagung-titi-contoh-nyata-bagaimanamasyarakat-lamaholot-menciptakan-ketahanan-pangan/

Hardiman, F. B. (2015). Seni Memahami. Yogyakarta: Kanisius.

Hidayat, M. A. (2008). Kebudayaan Posmodern Menurut Jean Baudrillard. Retrieved on November 4, 2020, from https:// fordiletante.wordpress.com/2008/04/15/kebudayaanpostmodern-menurut-jean-baudrillard/: https://fordiletante.wordpress.com/2008/04/15/kebudayaanpostmodern-menurut-jean-baudrillard/

Kleden, P. B. (2009). http://novel-cerita-indonesia.blogspot.com. Retrieved on Juni 16 , 2011, from http://novel-ceritaindonesia.blogspot.com;http://novel-cerita-indonesia. blogspot.com

Kusumo, J. I. (2018). Informasi Pembuatan Minuman Beralkohol di Indonesia. Retrieved on November 2020, from repository.unika.ac.id.

Maknun, M. L., \& Muzayanah, U. (2020). Contextualization Of Suluk Candra's CharacteR Values. Heritage of Nusantara: International Journal of Religious Literature and Heritage, 1.

Morton, S. (2008). Gayatri Spivak: Etika, Subaltern dan Kritik Penalaran Poskolonial. Yogyakarta: Pararaton.

Nadeak, O. (2019). "NTT To Legalize Traditional Alcoholic Drinks For Export Purposes", Floresplus Discovery the Hidden Paradise. Retrieved on November 4, 2020, from NTT To Legalize Traditional Alcoholic Drinks For Export Purposes", Floresplus Discovery the Hidden Paradise: https://www.floresplus.net/traditional-alcoholic-drinks-mokeand-sopi/

192 |VOL. 9 NO. 2 DECEMBER 2020 
Orong, Y., \& et.al. (2019). Menulis Kenangan, Merawat Harapan (STFK Ledalero Separuh Abad). Maumere: Penerbit Ledalero.

Piliang, Y. A. (2010). Postrealitas, Realitas Kebudayaan dalam Era Postmetafisika. Yogyakarta: Jalasutra.

Piliang, Y. A. (2011). Dunia yang Dilipat. Bandung: Matahari.

Ratna, N. K. (2010). Teori, Metode, dan Teknik Penelitian Sastra . Yogyakarta: Pustaka Pelajar.

Santoso, H. (2009). Metode Dekonstruksi Jacques Derrida: . Dalam L. Santoso, Epistemologi Kiri (hal. 247-248). Yogyakarta: Ar-Ruzz media.

Sindunata. (2007, November-Desember). Air Mata Ibu Tercinta. Basis, hal. 3.

Swasono, I. H. (2007). Dekonstruksi Diri Sendiri dalam Proses Penciptaan Karya Seni. Imaji, Jurnal Seni dan Pendidikan Seni Vol. 5, No. 2, 2007.

Tana, Y. F. (2020). Memahami Teori Dekonstruksi Jacques Derrida sebagai Hermeneutika Radikal. Retrieved on November 2020, from LSF Discourse, Ex Philosophia Claritas: https://lsfdiscourse.org/memahami-teori-dekonstruksi-jacquesderrida-sebagai-hermeneutika-radikal

Waligereja Indonesia, K. W. (2007). Katekismus Gereja Katolik. Ende: Nusa Indah.

Weber, E. (2005). Deconstruction is Justice, Article Special Issue, A Dedication to Jacques Derrida. German Law Journal. 
Corn \& Arak (Local Alcohol) as an Alternative ...

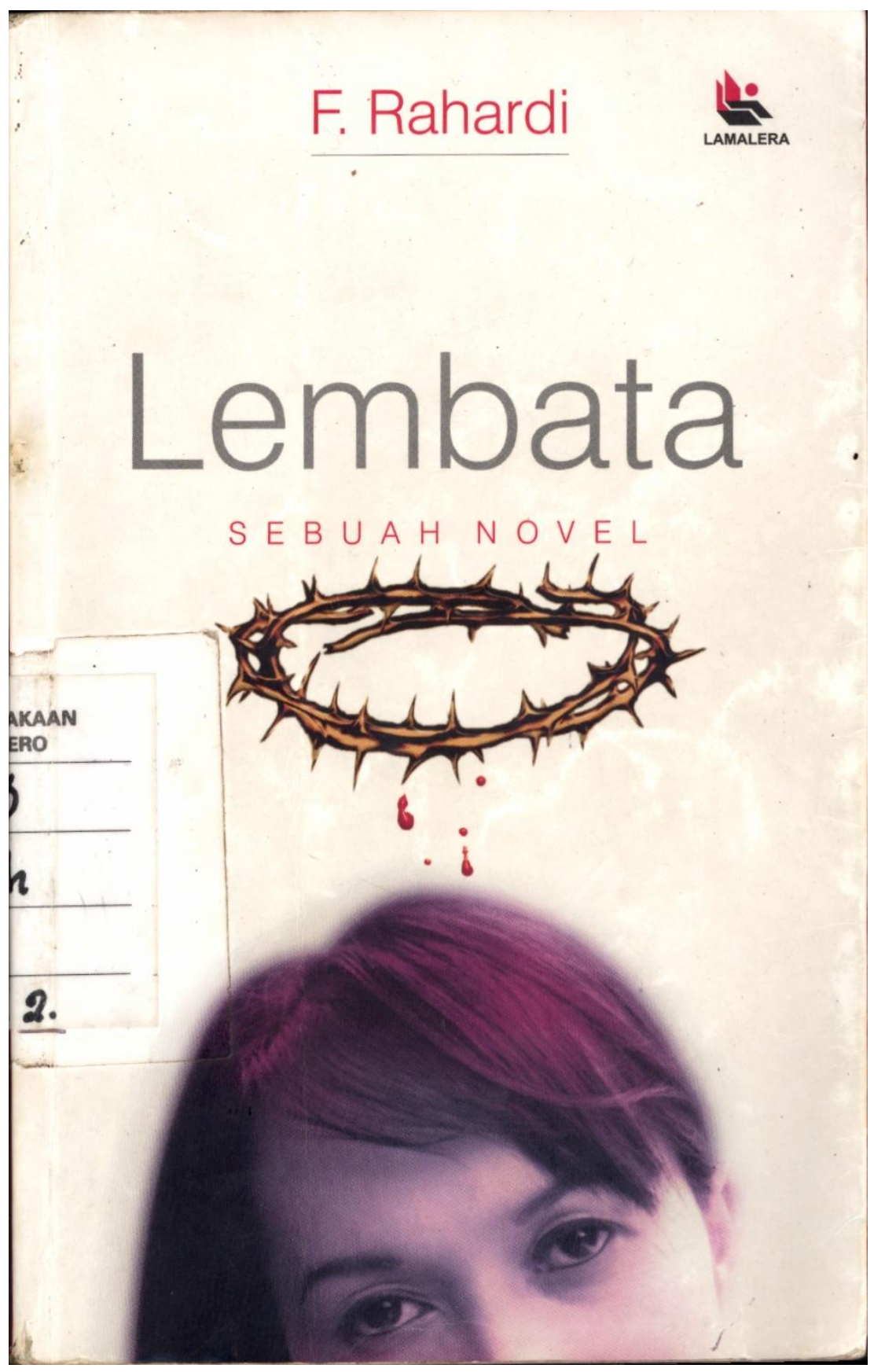

194 |VOL. 9 NO. 2 DECEMBER 2020 


\section{Lembata}

.."Baik, aku akan telanjang bulat Pedro. Sekarang kita hanya berdua. Kamu sudah bukan imam lagi. Apa masih takut kamu pada Uskup? Tidak ada urusan lagi bukan?Pedro, sekarang aku akan serahkan tubuh ini padamu, seperti dulu Yesus menyerahkan tubuhnya ke Laskar Romawi untuk dicambuk, dan disalibkan. Pedro, salibkan aku. Pentanglah tangan dan kakiku, paku dan pukullah dengan palu yang keras di dua tepi bed itu Pedro. Tusuklah aku dengan tombakmu Pedro, aku siap mati di tanganmu. Pedro, kamu tidak impoten bukan?Kamu sudah ereksi bukan? Ayo Pedro", ungkap Luciola dengan nada memelas.

Atribut maupun doktrin keagamaan seringkali dipakai sebagai sarana yang sangat ampuh untuk menghalalkan kejahatan, termasuk kecenderungan-kecenderungan instingtif yang liar. Karena itu perlu ada kehati-hatian untuk memilah milah manakah yang sumpal dan yang henar, yang palsu dan yang murni. Di tengah geliat zaman yang semakin bergelora sulit sekali untuk menemukan agamawan sekuat dan sejantan Pedro, ye berani untuk menyatakan 'tidak' pada ketelanjangan Luciola.

"Di tempat ziarah Lourdes, Pater Bona, yang sedang s Liturgi di Gregoriana akhirnya mengiyakan bujukan Luciola, gadis Mani yang dijuluki "kuda binal" oleh geng Ekonomi di Atmajaya, Jakarta. Den! dalih ziarah dan bimbingan spiritual, Luciola berhasil tidur sekamar den! Pater Bona. Dan terjadilah.

Secara sangat dramatis novel ini mengangkat sisi kehidupan yang 'lain' lebih sering tenggelam dalam ketokohan para hirarki Gereja serta hiruk p ritual dan tradisi keagamaan. Kerapkali tanpa disadari atau sengaja disadari bahwa sisi kehidupan yang 'lain' itu pun sudah banyak merembesi dinding - dinding biara yang kokoh dan berhasil mengumbar hasrat libidis tokoh-tokoh Gereja yang sudah (terlanjur) dianggap soleh.

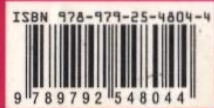

HERITAGE OF NUSANTARA: INTERNATIONAL JOURNAL OF RELIGIOUS LITERATURE AND HERITAGE 
Corn \& Arak (Local Alcohol) as an Alternative ...

\section{Lembata}

SEBUAH NOVEL

$\begin{array}{ll}\text { Penulis } & \text { :F. Rahardi } \\ \text { Penyunting } & \text { : Weni \& Bona Beding } \\ \text { Desain Cover } & \text { : Ong Hari Wahyu } \\ \text { Tata letak } & \text { : Nur Hidayat } \\ \text { Foto F. Rahardi } & \text { : Armin DP, (Majaiah Flona) }\end{array}$

Hak Cipta dilindungi undang - undang.

Dilarang mengutip atau memperbanyak sebagian atau seluruh isi buku ini tanpa izin tertulis dari penerbit lamalera.

Cetakan 1, Juli 2008

Penerbit Lamalera

Jl. Ikan Paus No. 1, Gesikan III RT.01

Desa Wijirejo, Kecamatan Pandak

Bantul - Yogyakarta 555761

Telp. 081319800085; 081315362141

e-mail:penerbitlamalera @yahoo.com

Perpustakaan Nasional: Katalog Dalam Terbitan (KDT)

Lembata, Sebuah Novel

Cetakan I, Yogyakarta: Penerbit Lamalera, 2008, X + 258; $12 X 19 \mathrm{Cm}$

ISBN: 978-979-25-4804-4

Dicetak oleh:

Titian Galang Printika

Jl. Madukismo, Bugisan selatan No. 15A. Yogyakarta 55181

Telp./Fax.: (0274) 387928; e-mmail: galang_printika 2005@yahoo.com

iv

196 |VOL. 9 NO. 2 DECEMBER 2020 